\title{
Ethics, genetics and pediatrics
}

\section{Ricardo Timm de Souza, ${ }^{1}$ José Roberto Goldim²}

\begin{abstract}
Objectives: To reflect on the nature of ethics, from a contemporary perspective, and also on which features of the family relationship have an impact on the interface between genetics and pediatrics.
\end{abstract}

Sources: The data used are the fruit of the authors' own intellectual production plus other bibliographic references.

Summary of the findings: Genetics has presented ethics with new challenges. Particularly in pediatrics, where caring for patients is almost indivisible from a continuous relationship with their families, these issues are amplified even further, generating new questions that health professionals have not previously had to face.

Conclusions: Based on the reflections outlined here, emphasis can be placed on the importance of actively recognizing the Other in its multiple dimensions and on the repercussions that this perspective has for the physician-patient-family relationship.

J Pediatr (Rio J). 2008;84(4 Suppl):S2-7: Ethics, genetics, family.

\section{Ethics}

As a first step, it is necessary to define what, in this context, we understand by ethics. ${ }^{1}$ In truth, there are countless possibilities for what the concept can be understood to mean, and entire libraries have been written on the question in terms of its philosophical meaning and origins. However, our primary interest here is the meaning of the word in the modern world. One particular observation is appropriate at this point: as with each and every word, this one has changed over time, incorporated new meanings, become more refined and diversified. The question, therefore, is posed in the following form: what are - or should be - the meanings conveyed by this term today? The answer, against the background of the complexity of the modern world, is equally multiple; however, it is necessary that, from within this multiplicity of possible and viable meanings, we emphasize that which allows us to best approach the subject of interest here, i.e., the intimate link between ethics and caring for human life. ${ }^{2}$ To us, this appears to be the following, ethics is the construction of the meaning of human life from the encounter with the Other." ${ }^{3}$ To follow, we will examine the meaning of this statement, based on a brief examination of the terms "Other," "encounter" and "caring."

\section{The Other}

We begin with the term "Other." In the present context, we understand the "Other" to be that which comes from outside, outside of the scope of my intellectual power, of my capacity for representation, of my intelligence which sees and assesses the world. The Other breaks the safety of my world, it always arrives unexpectedly, its presence is unpredictable and I have no way to neutralize, to eliminate, its presence and its meaning. If thought functions normally in terms of syntheses, i.e. by the process of reducing the Other to the Same by means of the classifications that we make constantly, ${ }^{4}$ this logic is broken, since the thought, the I that thinks, finds someone, someone who may say "no" to my "yes," someone who denies any type of explanation of its existence, its presence, for any logical or classificatory route. In the background this Other, itself, remains, and, in spite of this, is

1. Filósofo. Doutor em Filosofia. Professor, Instituto de Filosofia e Ciências Humanas (IFCH), Pontifícia Universidade Católica do Rio Grande do Sul (PUCRS), Porto Alegre, RS, Brazil. Responsável, Escritório de Ética na Pesquisa, Pró-Reitoria de Pesquisa e Pós-Graduação, PUCRS, Porto Alegre, RS, Brazil. Coordenador, Comitê de Ética para o Desenvolvimento Científico e Tecnológico (CEDECIT), PUCRS, Porto Alegre, RS, Brazil.

2. Biólogo. Doutor em Medicina. Professor, Faculdade de Medicina, PUCRS, Porto Alegre, RS, Brazil. Coordenador, Comitê de Ética em Pesquisa, PUCRS, Porto Alegre, RS, Brazil. Pesquisador responsável, laboratório de Pesquisa em Bioética e Ética na Ciência, Hospital de Clínicas de Porto Alegre (HCPA), Porto Alegre, RS, Brazil.

No conflicts of interest declared concerning the publication of this article.

Suggested citation: de Souza RT, Goldim JR. Ethics, genetics and pediatrics. J Pediatr (Rio J). 2008;84(4 Suppl):S2-7.

doi:10.2223/JPED.1792 
sufficiently close to me to oblige me to perceive its existence as absolutely real.

Therefore, what the Other originally represents to me is not just a theoretical problem, but a concrete event that destabilizes the certainties of my intelligence. I cannot, in any way whatsoever, determine that which the Other is as long as it remains that which it is, I cannot say what it really is: I can merely say what I manage to capture of it, what of it I can perceive and classify. Strictly speaking, the only thing that I can venture to say with respect of this Other is determined precisely by that Other itself: that it is of another manner otherly - that I, or rather, between us, a true and irreducible difference holds sway. ${ }^{5}$

However, despite this difference that we cannot overcome either by intelligence or knowledge, we can approach one another. The differences remain, but we can encounter one another. This encounter will not be a theoretical question - since, were it to be so, we would be back in the field of mental representation, in the field of the idea of the "other" that we already have - but a question that is fundamentally ethical, practical, since it deals with the concrete Other with which we encounter, and not an image of it. When we really meet someone, we do not at first "resolve" this other person in our minds, we do not consider them an object, a function that they perform or some number or other, we consider them to be an Other that may say "no" to my "yes," and to which we do not attribute a classification, but of whom we ask their name; and this we call an "encounter."6

\section{The encounter}

Here, "encounter," in the first instance, means to be open to the Other, i.e., to the not-yet-known. What is meant by this is not only one of the easiest things to imagine, but also one of the hardest things to achieve. This is because this openness implies my finding myself in a position that could radically be called into question, in a position of insecurity, by the mere appearance of alteration (from the Latin alter, other), that is to say, the condition of other in relation to me. ${ }^{4}$

And this is because no promise of conciliation comes from the Other, just an understanding that the totality of my conceptions are unable to do it justice. I cannot, truly, explain it, I can only, in radical terms, relate to it. The Other, which is not simply placed in front of me, which is not, in relation to me, any kind of object, but which comes to me, signifies, to the extent that it remains other, a new event, unexpected, traumatic.

On the other hand this does not only signify a radical insecurity on my part, but also - and most importantly - the possibility, or even a positive necessity, of a new beginning, starting from an irreversible rupture of my cognitive self-reference. For I must restart the process of understanding the world in which this encounter has taken place, since my representations and cosmovisions, adequate as they were for the comfort of my previous logical position, are unable to deal with the event that the emergence of the other in my world signifies. Ethics demand, so to speak, a different logic from the logic of intelligence, and this is intended to mean that ethics - expressed in the real encounter demands a different type of rationality, different from that which I use normally to deal with things and concepts - specifically, an ethical rationality, or, in more simple terms, a rationality of the encounter with the other. ${ }^{3}$

\section{Encounter-driven thinking}

The form in which the world is originally conceived determines, to a certain extent, the rationality of that world, the form in which it is understood later. If the world is not initially conceived and thought of in terms of abstract principles or in terms of the interactions of interests of power, pure and simple, but in terms of real human encounters in their infinite variety, this means that it is possible to conceive of another rationality in the midst of those that already exist - an ethical rationality. $^{7}$

However, one might question whether the mere idea of an ethical rationality does not sound, to a certain extent, unreal: an unrealistic task or construction.

One answer is already sketched out in principle: what is very real is the absolute necessity for such a rationality, unless we understand human beings to be cogs in a machine and intend to substitute human meaning whatever that may be for the instrumental meaning of alienation of the human in things, powers and violence.

However, the idea of an ethical rationality does not presuppose that each and every concept of reality and of the world that has existed to date should be abandoned in order to institute something completely new. What is being said here is that a unitary view of the world, based, for example, on exclusively scientific schema, is incapable of doing justice to the real human world. No mathematical reasoning, for example, can transcend its specific scope and propose itself as the fundamentals of a human world, of the truly human action that is to relate to another - unless, by "human," one understands mathematical entities. This is because the primordial question of action is always at the foundation. Where is my action founded, when I act? What is the reference that holds me in reality?

We can pose the question in reverse. How can we avoid referring our actions to the world of human relationships? What monstrous abstract force would allow us such a thing? How could we in some way conceive that some prior idea could, with determinant and maximum generality, indicate and support my relationship with the other, if my relationship with the Other is only "now," at the moment of the encounter, beginning ${ }^{4}$ 
There appears, therefore, to be just one path left: not to remain alone with my ideas, but to accept - to encounter the Other with all seriousness.

\section{Construction of human meaning: caring}

But, to what does this encounter with the Other in all seriousness lead us? Certainly not to a new scientific or philosophical theory like any other. In that case we would still be locked to our solitary thinking and the encounter would not have changed anything. It is necessary that something is born from this encounter. ${ }^{7}$

What could be born of this encounter, among many other things, is the answer to a major philosophical question, an answer that many philosophers have sought in the interior of their intelligence or within the confines of the universe for many centuries: the question of the meaning of human existence. Since, in truth, someone who is swimming in a true human encounter, for example, in an amorous encounter, does not question the meaning of existence, or of anything else: they concern themselves with living this encounter based on the meaning that the encounter itself offers. To encounter the Other means, therefore, much more than a trivial event like any other; it means finding a reason to live, a motive to continue in existence, a reason to care. Over the long term, it means the possibility of constructing a human meaning in the midst of the bitterness and difficulties of life. For, why do we live, if not for encounters, encounters with the ever-new reality that beats to the rhythm of the time that passes? Each human being, immersed in the multiplicity of beings, also brings their own vocation for multiplicity; their solitary existence pulls them out, beyond themselves, to the Other which is beyond their ideas, their prejudices, beyond even their needs. ${ }^{8}$

Ethics - the true encounter with the Other - is not therefore, in this sense, a theoretical discipline or some type of code, but the fundamental meaning of human life as long as that life lasts: it is the foundation for caring. The mother of all philosophies, ethics allows me to come out of myself and meet what is beyond myself, providing the opportunity for rationality to flower, a rationality that understands the world from the perspective of the meaning of the encounter. For things also present a face that invites encounter - as Art knows so well and reality assumes the significance of an invitation to a relationship - but to a relationship of caring. It is perhaps there, and not in the discovery of the latest galaxy or subatomic particle, that the seed of human meaning lies; whether or not this be so, a human cannot find meaning without the Other, since it is not even imaginable: we are born of Others, we meet with Others, we are in turn the fathers and mothers of Others. ${ }^{9}$

\section{The family}

The family is possibly the best expression of the relationships between interrelated Others, consequently generating ethical questions as a result of their meetings. ${ }^{10}$ We can think of several different concepts that should be taken up when discussing ethical issues related to family relationships, ${ }^{11}$ such as: family members are not substitutable for similar or for better qualified people; family members are bound to each other; the need for intimacy generates responsibility; to cause a person to come into existence generates responsibilities; virtues are learnt on mothers' and fathers' knees; families are histories in progress; and, finally, in families, motives count for much.

\section{The family and non-substitution}

The members of a family are not substitutable for similar or for better qualified people. In contrast with the employees of an organization, members of a family cannot be substituted for other people on the basis of the criterion of qualifications. Organizations are structured in order to achieve a given end that is external to them. Families, in contrast, are their own ends. In situations of family rearrangement, such as separations and remarriages, the impact on the lives of family members is much greater and goes far deeper than what is observed when organizations are sold, wound up or merged. ${ }^{11}$

It is in recognition of this non-substitutability that adoption programs attempt to keep siblings from the same family of origin together. For the same reason, many people who have been adopted or conceived from donated gametes may wish to know their biological origins.

When a family loses a child, some health professionals will advise that it is not a good idea to have another child to substitute the first. The loss of a child cannot be repaired by substitution, it can be understood and even accepted. One family member cannot be substituted by an Other, who will be recognized not as the lost one, but as someone who comes with the mission of repairing a loss.

\section{The family and its bonds}

Family members have bonds with each other. The members of the family are not chosen, with the exception of marriage and adoption. Relationships of kinship are based on biological, political and historical relationships, and not on contractual clauses. Siblings have biological bonds with each other and with their parents that go far beyond the limits of simple friendship. Other members join the family due to new bonds that are established by means of emotional relationships, such as, for example, marriages. People from different biological families come to have new shared histories, bringing with them all their previous bonds, which may facilitate, or cause problems for, their own relationship. ${ }^{11}$ Diagnostic testing for genetic diseases or predispositions is one of the greatest current challenges to professionals involved in caring for children. The justification for testing should be based on possible benefits associated with the diagnosis, which can range from cure to reduction of possible damage or compromise during development. Diagnoses of genetic diseases can 
demonstrate how these bonds materialize and recover their meaning.

Many statements given by young patients who have undergone diagnostic testing for familial adenomatous polyposis reflect this feeling of family bonds. One adolescence who was given a negative test result but had a sister already manifesting the disease said "I think I sort of felt a bit guilty because she ended up having it and I didn't". ${ }^{12}$ In another report, an adolescent described her parents' discomfort about her diagnosis. She described how, "When my dad realized I had it, he went and sat in the bedroom and didn't come out for like 2 hours... that really upset me when I saw what it did to my parents." 12

In contrast, a positive diagnosis of the same disease strengthened the bond. An adolescent heard the following from another member of her family who also had the disease: "You're one of us now." ${ }^{12}$ In another description, an adolescent says that the diagnosis meant that the family had "a special bond and we're closer now than we were before then."12

These reports demonstrate the variability of the reactions caused by situations where diagnoses reveal family bonds.

\section{The family, intimacy and responsibility}

In families, motives count for a great deal. In Nicomachean Ethics, ${ }^{13}$ Aristotle claimed that between people who are intimate, intentions are everything. Motivation is a differentiating factor in establishing intimacy. Our perception of people's motivation can change our assessment of them and their actions. In families, actions motivated by duty have less significance than those motivated by love. In "A Doll's House," Henrik Ibsen wrote that family life ceases to be free and beautiful when it is based on tedium and obligation. ${ }^{14}$

The need for intimacy generates responsibility. An intimate relationship involves relaxing defences and increases the volume of personal information that is shared. Intimacy creates opportunities for personal growth, widens the chances of getting to know ourselves and the Others with whom we share this relationship better. Intimacy creates spaces of interpersonal enrichment. Intimacy occurs when there is trust, when a person recognizes in another the responsibility necessary to deal with this information safely. The duty associated with access to this information is confidentiality, which is a moral duty. In counterpoint, intimate relationships also involve risk, which comes from increased vulnerability. If one member of a family inappropriately reveals the family's intimacy, damage is caused to all members, since everybody becomes vulnerable, in a position in which their private lives could become public.

Revealing a personal diagnosis of genetic disease, whether a patient or a carrier, to another person with whom one is having an intimate relationship may be seen as a barrier by many young people. This barrier might be associated with the difficulty involved in revealing a personal situation, which will expose the entire family, and also with the repercussions for a person's own reproductive future, primarily with relation to having a child who is equally affected. ${ }^{15}$

\section{The family and responsibility for making another person come into existence}

Causing another person to come into existence generates responsibilities. Conceiving a child creates an unending bond of responsibilities, particularly during the first years of life. This moral bond is manifest even as early as planning to conceive. Aristotle said that parents have the obligatory duty of caring for their children. ${ }^{13}$

The book La Gaviota, by Cecília Böhl von Faber, published under the pseudonym of Fernán Caballero, ${ }^{16}$ and which is considered one of the classic texts of Spanish literature, contains an excellent dialogue dealing with the question of parents' duties to their children.

Aunt Maria: How would it appear to you, child of my entrails, if I were to say to you: I gave birth to you, I brought you up, I have set you on the path; I have, therefore, fulfilled my obligation? If I saw a mother's love as no more than obligation?

Manuel: That my lady were not a good mother. ${ }^{16}$

Nowadays, the question of responsibility and obligation grows in importance when assisted reproduction and genetic diagnosis are being discussed. Responsibility for future consequences can be imputed if there is prior knowledge of the circumstances involved. If it is not possible to predict certain circumstances, which could thereby be avoided, then the universal nature of a particular event must be recognized. With respect to responsibility, intention provides the link between subjectivity and objectivity. ${ }^{17}$

Today, countless new choices are offered to parents, from before they conceive their children up to after their birth. ${ }^{18}$ Couples who wouldn't have been able to have children can now take advantage of new reproductive technologies that may allow them to realize their desire to reproduce. It is now possible to diagnose countless diseases that were not previously diagnosable and were not, or still are not, known of by the majority of the population. New knowledge has made it possible to understand the mechanisms by which some diseases are transmitted and manifest, with obvious repercussions for parents. These new possibilities and knowledge are associated with new responsibilities, such as, for example, the possibility of having a different genetic lineage from the social family with whom one lives, of making preconceptional diagnoses, of selecting the sex and other characteristics of children. These new ethical challenges must be faced with new and progressively more complex reflections on the circumstances and consequences involved. ${ }^{19}$

Assisted reproduction using donated gametes or even adoption itself may lead to the consequence of a desire or need to have access to one's genetic lineage. In such situations, 
revealing this information involves countless other people, in addition to the family itself. The confidentiality of biological parents, which may be guaranteed by contract or legislation, can be called into question by attempts to meet these demands for access to lineage, for healthcare motives. One of the greatest difficulties is to reconcile the multiple interests existing in the present with guarantees granted in the past.

Sex selection can be used in the sense that it is possible to prevent the birth of a child of a specific sex. The demand may spring from an interest in impeding transmission of an undesirable genetic characteristic which it is known will cause suffering either to the child who is a carrier or their parents, or may originate in other motivation of a social or cultural nature. ${ }^{20}$ Irrespective of ethical issues, the possibility of employing assisted reproduction techniques specifically in order to select embryos of a specific sex can also throw up regulatory problems. In Brazil, the only document that regulates this activity is the Federal Medical Council's (Conselho Federal de Medicina) Resolution 1358/92, which states that this type of procedure should be used to solve problems of human infertility. ${ }^{21}$

One question with which it is extremely difficult to deal is the issue of preferentially selecting a baby who is a carrier of a disability. This type of demand has already been made several times in different parts of the world by deaf couples, for example. ${ }^{18}$ Some authors have employed an argument stating that the very criterion of disability is itself arbitrary and as such can be questioned. In this specific case, the deaf community itself could be considered an independent culture. ${ }^{22}$ This argument is similar to the one used to defend selecting a sex for cultural or social reasons. According to these authors, fulfilling parents' desires should lead healthcare professionals to question the ability of people who are different from each other to live together, and should not cause discomfort due to participating in an artificial and directed selection of a human being with a disability. ${ }^{22}$ Obligation must pass between the boundaries between desire and need. It is always worth remembering the possibility of "slippery slope" phenomena, i.e., small concessions can lead to a growing increase in what can be tolerated with relation to a specific demand. ${ }^{23}$

\section{The family and time}

Families are histories in progress. Family members are always influenced by the histories of their relatives. Family situations are dynamic and not static. They very often exhibit a specific pattern of functioning, but even this pattern can be changed. Family decisions are based on this notion of process, of successive situations. What guarantees the stability of a family relationship is not the maintenance of a state, but the understanding of the possibility of change. ${ }^{11}$

Adaptability to change can be challenged by countless situations associated with diagnosis of genetic diseases. This may become more difficult when a test its predictive of a disease with late onset. In such cases, making a diagnosis may result in the emergence of the stigma of the "healthy sick", i.e., a child or adolescent who it is known will come to have a disease, but who is as yet free of any of the symptoms associated with it. When this demand is accepted, patients and their families receive an array of information that no one can erase and which will remain permanently present as a future threat. ${ }^{24}$

Statements made by young people with diagnoses of Huntington disease have made it possible to better understand these issues. One young person stated that knowing her diagnosis had benefited her, "Allowing me to live my life... allowing me to accept that and just live."12 Another, however, regretted the passage of time, saying that he should not have attended his final year of school, but should have, "taken time out for myself."12 Another important issue is related to the uncertainty suffered during the process of diagnosis. One young woman said, "I don't care if it was positive or negative, but actually finding out." ${ }^{12}$ Another young woman with a positive diagnosis said that the process of genetic counseling had helped her to understand the problem she was going to have to face. ${ }^{12}$

In David Copperfield, Charles Dickens wrote that, "accidents will occur in the best regulated families." 25 One family, whose notion of stability is as a state, might suffer an unpredictable shock when given bad news, whereas another, whose understanding of stability is as a process, would possibly be in a better position to face this challenge creatively as a result of strategies it has already employed in other situations.

\section{Final comments}

Ethics is not something that is secondary or an adornment to life, but the most profound component of life itself which, in the process of the encounter with that of which it is formed, gives it meaning. The concrete form that ethics can assume in everyday existence is as simple in its general formulation as it is complex in terms of its daily performance: caring. Since to care is to construct, in the careful preservation of the alterity of the other, the reason for the endurance in each and every sense of the term - of life itself. ${ }^{2}$

\section{References}

1. Souza RT. Ética como fundamento - uma introdução à ética contemporânea. São Leopoldo, RS: Nova Harmonia; 2004.

2. Souza RT. Fontes do humanismo latino - a condição humana no pensamento filosófico moderno e contemporâneo. Porto Alegre, RS: EDIPUCRS; 2004.

3. Souza RT. Razões plurais. Porto Alegre, RS: EDIPUCRS; 2004.

4. Souza RT. Sentido e alteridade - dez ensaios sobre o pensamento de E. Levinas. Porto Alegre, RS: EDIPUCRS; 2000. 
5. Souza RT. Em torno à diferença - aventuras da alteridade na complexidade da cultura contemporânea. Rio de Janeiro: Lumen Juris; 2008.

6. Souza RT. Nós e os outros. Sobre a questão do humanismo, hoje. In: Paviani J, DalRi Jr A, editores. Globalização e humanismo latino. Porto Alegre, RS: EDIPUCRS; 2000. p. 203-12.

7. Souza RT. Sobre a construção do sentido - o pensar e o agir entre a vida e a filosofia. São Paulo, SP: Perspectiva; 2004.

8. Souza RT. Sujeito, ética e história - Levinas, o traumatismo infinito e a crítica da filosofia ocidental. Porto Alegre: EDIPUCRS; 1999.

9. Souza RT. O tempo e a Máquina do Tempo - estudos de filosofia e pós-modernidade. Porto Alegre, RS: EDIPUCRS; 1998.

10. Goldim JR. Bioética e família. In: Souza IM, editor. Casamento: uma escuta além do Judiciário. Florianópolis, SC: VoxLegem; 2006. p. 539-42.

11. Nelson HL, Nelson JL. The patient in the family: an ethics of Medicine and families. New York, NY: Routledge; 1995.

12. Duncan RE, Gillam L, Savulescu J, Williamson R, Rogers JG, Delatycki MB. "You're one of us now": young people describe their experiences of predictive genetic testing for Huntington disease (HD) and familial adenomatous polyposis (FAP). Am J Med Genet C Semin Med Genet. 2008;148:47-55.

13. Aristóteles. Ética a Nicômacos. Brasília, DF: EDUNB; 1985.

14. Ibsen H. Teatro. São Paulo, SP: Cultura; 1942.

15. McConkie-Rosell A, Spiridigliozzi GA, Melvin E, Dawson DV, Lachiewicz EM. Living with genetic risk: effect on adolescent self-concept. Am J Med Genet C Semin Med Genet. 2008;148: 56-69.

16. Caballero F. La Gaviota. Madrid: Castalia; 1861(1849). p. 72.
17. Weber T. Ética e filosofia política: Hegel e o formalismo kantiano. Porto Alegre, RS: EDIPUCRS; 1999.

18. Davis DS. Genetic Dilemmas: reproductive technology, parental choices and children's future. New York, NY: Routledge; 2001.

19. Goldim JR. Bioética: origens e complexidade. Revista HCPA. 2006;26:86-92.

20. Clotet J, Goldim JR. Seleção de sexo e bioética. Porto Alegre, RS: EDIPUCRS; 2004.

21. Conselho Federal de Medicina. Resolução 1358/92 - Normas Éticas para a Utilização das Técnicas de Reprodução Assistida. Diário Oficial da União Seção 1; 19/11/1992.

22. Arnos KS, Israel J, Cunningham M. Genetic counseling of the deaf: medical and cultural considerations. Ann N Y Acad Sci. $1991 ; 630: 212-22$.

23. Schauer F. Slippery slopes. Harv Law Rev. 1985;99:361-83.

24. Beck-Gernsheim E. Tem razão quem cura? Considerações sobre o uso social do diagnóstico e da terapia genética. In: DeBoni LA, Jacob G, Salzano FM, editores. Ética e genética. Porto Alegre, RS: EDIPUCRS; 1998. p. 251-75.

25. Dickens C. David Copperfield. London: Longman; 1973.

Correspondence:

José Roberto Goldim

Hospital de Clínicas de Porto Alegre

Grupo de Pesquisa e Pós-Graduação

Ramiro Barcellos, 2350

CEP 90035-903 - Porto Alegre, RS - Brazil

Tel.: +55 (51) 2101.8304

Fax: +55 (51) 2101.8526

E-mail: goldim@orion.ufrgs.br,

jgoldim@hcpa.ufrgs.br 